\title{
Improving the growth performance and cholesterol metabolism of rainbow trout (Oncorhynchus mykiss) fed soyabean meal-based diets using dietary cholesterol supplementation
}

\author{
Junming Deng ${ }^{1}$, Baoliang $\mathrm{Bi}^{1}$, Bin Kang ${ }^{2}$, Lingfu Kong ${ }^{1}$, Qiuju Wang ${ }^{1}$ and Xi Zhang ${ }^{1 *}$ \\ ${ }^{1}$ College of Animal Science and Technology, Yunnan Agricultural University, Kunming 650201, People's Republic of China \\ ${ }^{2}$ Asian International Rivers Center, Yunnan University, Cuibu North Road 2, Kunming, 650091, People's Republic of China \\ (Submitted 21 May 2012 - Final revision received 7 September 2012 - Accepted 13 September 2012 - First published online 27 November 2012)
}

\section{Abstract}

A 9-week feeding trial was conducted to evaluate the effects of dietary cholesterol supplementation at different levels $(0,0 \cdot 3,0 \cdot 6,0 \cdot 9,1 \cdot 2$ and $1.5 \%$ ) on growth and cholesterol metabolism of rainbow trout (Oncorbynchus mykiss) fed soyabean meal (SBM)-based diets. Daily growth coefficient (DGC) steadily increased when the supplemental cholesterol was increased by up to $1 \cdot 2 \%$, but declined upon further addition. The total cholesterol (TC), HDL-cholesterol (HDL-C) and LDL-cholesterol (LDL-C) levels in plasma generally increased when the supplemental cholesterol was increased by up to $1.2 \%$. Thereafter, the TC level reached a plateau, the LDL-C level showed a marked decline, whereas the HDL-C level continued to increase. Dietary cholesterol supplementation generally increased the total lipid and cholesterol levels in liver; the total lipid and TAG levels in muscle; the TC, free cholesterol, cholesteryl ester and total bile acid levels in intestinal contents; and the triiodothyronine and Ca levels in plasma. However, significant differences were mainly observed with high levels of supplemental cholesterol (0.9-1.5\%). Low levels of supplemental cholesterol (0.3-0.9\%) decreased hepatic 3-hydroxy-3methyl-glutaryl-CoA reductase and cholesterol $7 \alpha$-hydroxylase activities, but high levels of supplemental cholesterol (1.5\%) increased hepatic acyl-CoA:cholesterol acyl transferase and cholesterol $7 \alpha$-hydroxylase activities. These results suggest that rainbow trout fed SBM-based diets have a certain 'cholesterol-buffering capacity', which in turn suggests the possibility of the inhibition of exogenous cholesterol absorption and/or inadequate endogenous production of cholesterol in trout fed SBM-based diets. DGC increased steadily with increasing supplemental cholesterol level up to $1 \cdot 2 \%$, and the growth-promoting effects might be related to the alleviation of the negative effects caused by a soyabean diet and/or make up for the deficiency of endogenous cholesterol in rainbow trout.

\section{Key words: Rainbow trout: Cholesterol: Soyabean meal: Growth: Metabolism}

Replacing fishmeal (FM) with various protein sources has been investigated in aquafeeds due to the increasing demand, limited supply and high price of $\mathrm{FM}^{(1)}$. Soyabean meal (SBM) has been intensively studied as an alternative protein source because of its high protein content, relatively wellbalanced amino acid profiles, availability and reasonable $\operatorname{cost}^{(2)}$. However, the use of SBM in aquafeeds, especially for carnivorous fishes, is still limited because of its plant-origin characteristics, such as poor palatability, low nutrient digestibility, presence of certain anti-nutritional factors and the lack of several essential amino acids ${ }^{(3)}$. Thus, some essential amino acids, attractants and minerals are often supplemented when FM is replaced by SBM, but there are numerous essential nutrients that are often overlooked. For example, the increasing proportion of SBM in feed formulations will reduce the level of dietary cholesterol, which is rich in FM but deficient in $\mathrm{SBM}^{(4,5)}$. Feeds traditionally formulated with FM will provide at least $1 \mathrm{~g}$ cholesterol per $\mathrm{kg} \mathrm{feed}^{(5)}$. Thus, the replacement of FM with SBM will greatly reduce the dietary cholesterol level. On the other hand, soya proteins and non-protein compounds present in SBM (such as soya saponins and phytosterol) reportedly lower the blood cholesterol level in fish ${ }^{(6,7)}$. Thus, the cholesterol-lowering action has already been reported in many fish species fed diets with SBM instead of $\mathrm{FM}^{(2,8,9)}$. Moreover, the expression of several genes involved in the cholesterol biosynthesis pathway, such as 3-hydroxy-3-methyl-glutaryl-CoA reductase (HMGR) and lanosterol $14-\alpha$ demethylase, is up-regulated in fish fed diets

Abbreviations: ACAT, acyl-CoA:cholesterol acyl transferase; C0, basal diet; C3, 0.3\% cholesterol; C6, 0.6\% cholesterol; C9, 0.9\% cholesterol; C12, 1.2\% cholesterol; C15, 1.5\% cholesterol; CE, cholesteryl ester; CYP7A1, cholesterol $7 \alpha$-hydroxylase; DGC, daily growth coefficient; FC, free cholesterol; FM, fishmeal; HDL-C, HDL-cholesterol; HMGR, 3-hydroxy-3-methyl-glutaryl-CoA reductase; LDL-C, LDL-cholesterol; MBW, metabolic body weight; SBM, soyabean meal; $\mathrm{T}_{3}$, triiodothyronine; TBA, total bile acid; TC, total cholesterol. 
with high SBM levels, which suggests stimulation of the cholesterol biosynthesis pathway ${ }^{(10,11)}$. These findings strongly suggest that replacing FM with high levels of SBM may result in an inadequate supply of cholesterol in fish. Thus, the effects on cholesterol metabolism may be an area requiring consideration in the future as the proportion of SBM in dietary formulations increases ${ }^{(5)}$.

Cholesterol is a necessary constituent for eukaryotic cell growth and development. The biosynthesis of cholesterol provides crucial building blocks for cell membranogenesis and membrane fluid regulation ${ }^{(12)}$. In addition, cholesterol serves as a precursor of many physiologically active compounds, such as sex hormones, adrenal corticoids, bile acids and vitamin D. Thus, cholesterol plays an important role in maintaining the physiological functions of fish. Previous studies have shown that lower blood cholesterol levels are associated with lower growth performance in fish fed diets containing SBM instead of $\mathrm{FM}^{(8,13)}$ and higher mortality rates due to bacterial infections and occurrences of green liver ${ }^{(14,15)}$, suggesting the possibility that inadequate cholesterol might be limiting normal growth of fish fed SBM-based diets ${ }^{(16)}$. Cholesterol metabolism is affected by de novo cholesterol synthesis in the liver (endogenous cholesterol) and dietary cholesterol contents (exogenous cholesterol) ${ }^{(15)}$. Thus, we deem that dietary cholesterol supplementation may improve the growth performance of fish fed soya product-based diets, which has been demonstrated by previous studies ${ }^{(17-20)}$. However, there is no report on the potential mechanism of the growth promotion of dietary cholesterol so far. The objective of the present study was to determine the effect of increasing levels of cholesterol supplementation on the growth and cholesterol metabolism of rainbow trout (Oncorbynchus mykiss) fed SBM-based diets, and thereby to investigate the preliminary mechanism of growth-promoting effects of dietary cholesterol.

\section{Materials and methods}

\section{Experimental diets}

A total of six isonitrogenous (crude protein $43 \%$ ) and isoenergetic (gross energy $21 \mathrm{~kJ} / \mathrm{g}$ ) practical diets were formulated to contain increasing levels of cholesterol. A basal diet (C0) was formulated using a combination of FM (accounting for approximately $30 \%$ of the dietary protein) and SBM (about $70 \%$ ) as the primary protein sources. The other five diets (C3, C6, C9, C12 and C15) were supplemented with $0 \cdot 3,0 \cdot 6,0 \cdot 9,1 \cdot 2$ and $1.5 \%$ cholesterol (purity $\geq 99 \%$; Shanghai Shunbo Biotech Company, Limited) in place of wheat flour in the basal diet. The ingredients and the chemical composition of the diets are presented in Table 1 . The actual cholesterol content in the $\mathrm{C} 0, \mathrm{C} 3, \mathrm{C} 6, \mathrm{C} 9, \mathrm{C} 12$ and $\mathrm{C} 15$ diets were 0.38 , $0.68,1.03,1.37,1.68$ and $1.83 \%$, respectively.

Experimental ingredients were ground into fine powder by passing through a $320-\mu \mathrm{m}$ mesh. Cholesterol was pre-blended into fish oil. All the ingredients were thoroughly mixed with soyabean oil and fish oil, and water was added to produce a stiff dough, which was then extruded by a pellet feed maker
(KS-180, Jiangsu Jingu Rice Mill Company, Limited) through a $3 \mathrm{~mm}$ die. The moist pellets were dried in a forced air oven at room temperature for about $12 \mathrm{~h}$ and then stored at $-20^{\circ} \mathrm{C}$ until use.

\section{Experimental animals and conditions}

The present study was conducted according to the Regulations for the Administration of Affairs Concerning Experimental Animals approved by the State Council of the People's Republic of China on 31 October 1988. Rainbow trout (O. mykiss) were transported from a local commercial farm (Fenghong Fisheries Company, Limited) to the aquaculture laboratory at Yunnan Agricultural University (Kunming, China). Prior to the start of the experiment, the fish were acclimatised to the experimental tanks and fed a commercial diet (TR-2242, Salmofood S.A.) for 2 weeks. A total of 450 fish with an initial mean weight of $57 \cdot 81 \mathrm{~g}$ were randomly distributed in eighteen tanks with twenty-five juveniles per tank (triplicate groups per dietary treatment). The rectangular fibreglass aquaria $(1.0 \mathrm{~m} \times 0.7 \mathrm{~m} \times 0.8 \mathrm{~m})$ were supplied with continuous water flow and aeration. The water was recirculated through a 4000 litre biological and mechanical filtration system containing a vertical quartz sand filter and an activated carbon purifier to remove solid and nitrogenous wastes. During the experimental period, the temperature ranged from 14 to $18^{\circ} \mathrm{C}$, dissolved oxygen concentrations were $7 \cdot 3-8 \cdot 0 \mathrm{mg} / 1$ and $\mathrm{pH}$ was maintained at 6.7-6.9. The fish were subjected to a natural photoperiod and were hand fed to apparent satiation two times per d (08.00 and 16.00 hours) with one of the six experimental diets over a period of 9 weeks. Any uneaten feed was collected $1 \mathrm{~h}$ after every feeding, and the DM content was determined for both supplied and uneaten diets ${ }^{(21)}$. Leaching loss in the uneaten diets was estimated by leaving four samples of each diet in tanks without fish for $1 \mathrm{~h}$, followed by recovering, drying and reweighing them. Feed consumption was recorded by subtracting the amount of uneaten diet from total amount of diet fed on a DM basis. Fish were not pair-fed in the present study, as intakes were not expected to be different among the dietary treatments. Previous studies reported that dietary cholesterol content did not have any impact on feed intake using a two-choice preference test ${ }^{(22,23)}$.

\section{Sampling}

At the end of the feeding trial, the fish were fasted for $24 \mathrm{~h}$ before harvesting. All experimental fish were anaesthetised with eugenol (1:12000) (Shanghai Chemical Reagent Company, Limited) before sampling. The total number of fish was counted and the mean body weight of fish in each tank was measured to calculate growth performance and feed utilisation. A total of seven fish per tank at termination were randomly collected and stored frozen $\left(-20^{\circ} \mathrm{C}\right)$ for proximate composition analysis. Another seven fish per tank were sampled to analyse the plasma lipoprotein levels. Blood was collected from the caudal vein using a heparinised syringe and transferred into a heparinised tube. Plasma was recovered after centrifugation $(4000 \mathrm{~g}, 10 \mathrm{~min})$ at $4^{\circ} \mathrm{C}$ and immediately 
Table 1. Ingredients and proximate composition of the experimental diets for rainbow trout (Oncorhynchus mykiss)

\begin{tabular}{|c|c|c|c|c|c|c|}
\hline & \multicolumn{6}{|c|}{ Dietary treatments } \\
\hline & $\mathrm{CO}$ & $\mathrm{C} 3$ & C6 & $\mathrm{C9}$ & $\mathrm{C} 12$ & C15 \\
\hline \multicolumn{7}{|l|}{ Ingredients (\%) } \\
\hline Fish meal $^{*}$ & $20 \cdot 0$ & $20 \cdot 0$ & $20 \cdot 0$ & $20 \cdot 0$ & $20 \cdot 0$ & $20 \cdot 0$ \\
\hline Soyabean meal ${ }^{\star}$ & $57 \cdot 0$ & $57 \cdot 0$ & $57 \cdot 0$ & $57 \cdot 0$ & $57 \cdot 0$ & $57 \cdot 0$ \\
\hline Wheat flourt & 1.5 & 1.2 & 0.9 & 0.6 & 0.3 & 0.0 \\
\hline Soyabean lecithin $(40 \%) \ddagger$ & $5 \cdot 0$ & $5 \cdot 0$ & $5 \cdot 0$ & $5 \cdot 0$ & $5 \cdot 0$ & $5 \cdot 0$ \\
\hline Fish oil ${ }^{\star}$ & $5 \cdot 8$ & $5 \cdot 8$ & $5 \cdot 8$ & $5 \cdot 8$ & $5 \cdot 8$ & $5 \cdot 8$ \\
\hline Soya oil ${ }^{*}$ & 5.4 & 5.4 & 5.4 & 5.4 & 5.4 & 5.4 \\
\hline Choline chloride $(50 \%)^{*}$ & 0.5 & 0.5 & 0.5 & 0.5 & 0.5 & 0.5 \\
\hline Vitamin C§ & 0.2 & $0 \cdot 2$ & 0.2 & 0.2 & 0.2 & 0.2 \\
\hline $\mathrm{Ca}\left(\mathrm{H}_{2} \mathrm{PO}_{4}\right)_{2}{ }^{*}$ & 0.8 & 0.8 & 0.8 & 0.8 & 0.8 & 0.8 \\
\hline Ethoxyquin $(30 \%)^{*}$ & 0.05 & 0.05 & 0.05 & 0.05 & 0.05 & 0.05 \\
\hline L-Lys.HCl ${ }^{*}$ & 0.35 & 0.35 & 0.35 & 0.35 & 0.35 & 0.35 \\
\hline DL-Met* & 0.4 & 0.4 & 0.4 & 0.4 & 0.4 & 0.4 \\
\hline Mineral premix\| & 1.5 & 1.5 & 1.5 & 1.5 & 1.5 & 1.5 \\
\hline Vitamin premix & 1.5 & 1.5 & 1.5 & 1.5 & 1.5 & 1.5 \\
\hline Cholesterol $^{\star \star}$ & 0.0 & 0.3 & 0.6 & 0.9 & 1.2 & 1.5 \\
\hline \multicolumn{7}{|l|}{ Proximate composition } \\
\hline DM (\%) & $92 \cdot 74$ & $91 \cdot 86$ & 93.95 & 91.35 & $91 \cdot 82$ & 93.39 \\
\hline Crude protein (\% DM) & 43.45 & $43 \cdot 72$ & 43.37 & 43.47 & 43.49 & 43.56 \\
\hline Crude fat (\% DM) & $16 \cdot 98$ & 17.55 & $17 \cdot 29$ & $17 \cdot 36$ & $18 \cdot 16$ & 18.64 \\
\hline Ash (\% DM) & $10 \cdot 49$ & $10 \cdot 41$ & $10 \cdot 05$ & $10 \cdot 13$ & $10 \cdot 06$ & 10.09 \\
\hline Carbohydrate (\% DM)†† & $29 \cdot 08$ & $28 \cdot 32$ & 29.29 & 29.04 & $28 \cdot 29$ & $27 \cdot 71$ \\
\hline Neutral-detergent fibre (\% DM) & $9 \cdot 34$ & $9 \cdot 32$ & $9 \cdot 23$ & $9 \cdot 20$ & $9 \cdot 12$ & 9.03 \\
\hline Acid-detergent fibre (\% DM) & $5 \cdot 91$ & $5 \cdot 88$ & $5 \cdot 87$ & $5 \cdot 88$ & $5 \cdot 86$ & $5 \cdot 82$ \\
\hline 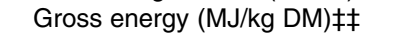 & $22 \cdot 01$ & $22 \cdot 16$ & $22 \cdot 15$ & $22 \cdot 15$ & $22 \cdot 35$ & 22.45 \\
\hline Cholesterol & 0.38 & 0.68 & 1.03 & 1.37 & 1.68 & 1.83 \\
\hline
\end{tabular}

C0, basal diet; C3, 0.3\% cholesterol; C6, 0.6\% cholesterol; C9, 0.9\% cholesterol; C12, $1.2 \%$ cholesterol; C15, $1.5 \%$ cholesterol.

* Supplied by Kunming Tianyuan Feed Company, Limited; fishmeal, $67.0 \%$ crude protein, $11.5 \%$ crude lipid; soyabean meal, $49.3 \%$ crude protein, $2.8 \%$ crude lipid.

† Supplied by Zhaoqing Four Gardener Flour Company, Limited, $12.9 \%$ crude protein, $2.8 \%$ crude lipid.

¥ Supplied by Shanghai Hanhong Chemical Company, Limited.

$\S \mathrm{L}$-Ascorbate-2-polyphosphate (35\%), supplied by Galaxy Chemicals Company, Limited.

II Mineral premix (g/kg of mixture): $\mathrm{MgSO}_{4} \cdot 7 \mathrm{H}_{2} \mathrm{O}, 180 \cdot 0 ; \mathrm{KI}, 1 \cdot 0 ; \mathrm{FeSO}_{4} \cdot \mathrm{H}_{2} \mathrm{O}, 260 ; \mathrm{ZnSO}_{4} \cdot \mathrm{H}_{2} \mathrm{O}, 180 ; \mathrm{CuSO}_{4} \cdot 5 \mathrm{H}_{2} \mathrm{O}$ $25 ; \mathrm{Na}_{2} \mathrm{Se}_{2} \mathrm{O}_{3}, 0.01 ; \mathrm{MnSO}_{4} \cdot \mathrm{H}_{2} \mathrm{O}, 180 ; \mathrm{CoCl}_{2} \cdot 6 \mathrm{H}_{2} \mathrm{O}, 0.75$

I Vitamin premix (g/kg of mixture): retinyl acetate, 2; cholecalciferol, 0.03; DL- $\alpha$-tocopheryl acetate, 30; menadione 3; thiamine hydrochloride, 8; riboflavin, 11; pyridoxine hydrochloride, 8; vitamin $\mathrm{B}_{12}, 0.02$; ascorbic acid, 50; folic acid, 1; biotin 0.1; niacin, 30; calcium D-pantothenate, 32; inositol, 25.

** Supplied by Shanghai Shunbo Biotech Company, Limited.

†† Carbohydrate $=100-$ (crude protein + crude fat + ash $)$

㧊Gross energy was calculated using the factors $39.5 \mathrm{~kJ} / \mathrm{g}$ for fat, $23.7 \mathrm{~kJ} / \mathrm{g}$ for protein and $17.2 \mathrm{~kJ} / \mathrm{g}$ for carbohydrate.

stored at $-80^{\circ} \mathrm{C}$ until analysis. The intestines were removed from the abdominal cavity, and the contents were squeezed out and mixed for lipid analysis. Liver and muscle samples were frozen in liquid $\mathrm{N}_{2}$ and then stored at $-80^{\circ} \mathrm{C}$ for subsequent determination. All samples were pooled by tank for analysis.

\section{Analyses}

Chemical analyses. Analysis of DM $\left(105^{\circ} \mathrm{C}, 24 \mathrm{~h}\right)$, crude protein (Kjeldahl $\mathrm{N} \times 6.25$ ), crude lipid (diethyl ether extraction via the Soxhlet method) and ash $\left(550^{\circ} \mathrm{C}, 18 \mathrm{~h}\right)$ in feed ingredients, experimental diets and whole-body samples was performed using standard laboratory procedures ${ }^{(24)}$. Carbohydrate was estimated as the weight difference using crude protein, crude lipid and ash content data. Neutral-detergent fibre and acid-detergent fibre were determined using the Association of Official Analytical Chemists official method ${ }^{(24)}$. Gross energy content was calculated using $23.7 \mathrm{~kJ} / \mathrm{g}$ of protein, $39.5 \mathrm{~kJ} / \mathrm{g}$ of lipid and $17 \cdot 2 \mathrm{~kJ} / \mathrm{g}$ of carbohydrate ${ }^{(25)}$.
Cholesterol and total bile acids analyses. The total cholesterol (TC), HDL-cholesterol (HDL-C) and TAG levels in plasma were determined without extraction using commercial enzymatic kits (Shanghai Jiemen Bio-Tech Company). Plasma LDL-cholesterol (LDL-C) level was calculated using the method described by Friedewald et $a l .{ }^{(26)}$. The TC content in the diets, liver, muscle and intestinal contents, and the TAG content in the liver and muscle were determined using the same enzymatic kits used for plasma, except these samples were extracted with chloroform-methanol (2:1, v/v), evaporated under $\mathrm{N}_{2}$ and then resuspended in chloroform according to the method of Folch et al. ${ }^{(27)}$. The total lipid content in fish liver and muscles were determined gravimetrically ${ }^{(27)}$ The free cholesterol (FC) and total bile acid (TBA) levels in the intestinal contents were measured using commercial ELISA kits for fish (R\&D Systems, Inc.), according to the manufacturer's protocols. The cholesteryl ester (CE) level in the intestinal contents was calculated by subtracting the FC value from the TC value. 
Plasma triiodothyronine, thyroxine, cortisol, calcium and phosphorus contents. Plasma thyroid hormone (thyroxine and triiodothyronine $\left(\mathrm{T}_{3}\right)$ ) levels were measured using RIA, as described by Martinez et al. ${ }^{(28)}$. Plasma cortisol was measured via RIA, as described by Metz et al. ${ }^{(29)}$. Plasma Ca and $\mathrm{P}$ levels were determined using commercial kits (Nanjing Jiancheng Biological Engineering Research Institute).

Hepatic acyl-CoA:cholesterol acyl transferase activity, 3-hydroxy-3-methyl-glutaryl-CoA reductase and cholesterol $7 \alpha$-hydroxylase activities. Microsomes were prepared according to the method described by Rasmussen et al. ${ }^{(30)}$ with a slight modification. Briefly, $1 \mathrm{~g}$ of liver tissue was homogenised in $4 \mathrm{ml}$ of ice-cold Tris-HCl buffer $(0 \cdot 1 \mathrm{M}$-Tris- $\mathrm{HCl}$ with $0.5 \mathrm{M}-\mathrm{KCl}, 1 \mathrm{~mm}$-EDTA and $0.1 \mathrm{~mm}$-phenylmethanesulfonyl fluoride; $\mathrm{pH} 7 \cdot 4)$. The homogenates were centrifuged twice at $10000 \mathrm{~g}$ and at $12000 \mathrm{~g}$ for $10 \mathrm{~min}$ at $4^{\circ} \mathrm{C}$. The supernatant liquids were then centrifuged twice in an ultracentrifuge at $100000 \mathrm{~g}$ for $60 \mathrm{~min}$ at $4^{\circ} \mathrm{C}$. The resulting microsomal pellets were then redissolved in $1 \mathrm{ml}$ of homogenation buffer to analyse the protein content, as well as acyl-CoA:cholesterol acyl transferase (ACAT), HMGR and cholesterol $7 \alpha$-hydroxylase (CYP7A1) activities. The ACAT, HMGR and CYP7A1 activities were measured using commercial ELISA kits for fish (R\&D Systems, Inc.), according to the manufacturer's protocols. The protein content in the microsomes was assayed according to the method described by Bradford ${ }^{(31)}$.

\section{Calculations}

The following formulae were applied to the data:

$$
\begin{aligned}
& \text { Mean metabolic body weight }(\mathrm{MBW}) \\
& \left.=\left(W_{\mathrm{i}} / 1000\right)^{0.75}+\left(W_{\mathrm{f}} / 1000\right)^{0.75}\right) / 2 \\
& \text { Daily growth coefficient }(\mathrm{DGC}, \% / \mathrm{d}) \\
& \quad=100 \times\left(W_{\mathrm{f}}^{1 / 3}-W_{\mathrm{i}}^{1 / 3}\right) / \mathrm{d} \\
& \text { Feed intake }(\mathrm{g} / \mathrm{kg} \mathrm{MBW} \text { per } \mathrm{d})=\mathrm{DI} / \mathrm{MBW} / \mathrm{d} \\
& \text { Feed efficiency }=\left(W_{\mathrm{f}}-W_{\mathrm{i}}\right) / \mathrm{DI}
\end{aligned}
$$

where $W_{\mathrm{i}}$ and $W_{\mathrm{f}}$ are the initial and final fish mean weights ( $g$ ), d is feeding days and DI is the dry diet intake per fish (g DM/fish) during the experimental period.

\section{Statistical analyses}

Percentage data were subjected to arcsine transformation before statistical analysis. All data were analysed using oneway ANOVA, followed by a Tukey's multiple comparisons test. The level of significance was set to $P<0 \cdot 05$. Statistical analysis was performed using SPSS 16.0 for Windows (SPSS, Inc.).

\section{Results}

\section{Survival and growth}

Survival rate of fish ranged from 88.9 to $100 \%$ and was nonsignificantly different among the dietary treatments (Table 2). Similarly, no significant differences in the first week feed intake ( $\mathrm{g} /$ fish) and total feed intake $(\mathrm{g} / \mathrm{kg}$ MBW per $\mathrm{d})$ were observed among the dietary treatments. The DGC increased steadily, as the levels of supplemental cholesterol were increased by up to $1.2 \%$ and then declined with further addition. Fish fed the C12 diet showed significantly higher feed efficiency compared with those fed the other diets. The final body compositions of fish were non-significantly affected by dietary cholesterol levels (Table 3).

\section{Cholesterol levels in plasma, liver, muscle and intestinal contents}

Dietary cholesterol content significantly affected plasma lipoprotein levels (Table 4). Fish fed the C9 diet showed a significantly higher plasma TAG level compared with those fed the C3, C6, C12 and C15 diets. The plasma TC level in fish fed the C9 diet was significantly higher than that in fish fed the C0, C3 and C6 diets, but lower than that in fish fed the $\mathrm{C} 12$ and $\mathrm{C} 15$ diets. The plasma HDL-C level was highest in fish fed the C12 diet and lowest in fish fed the C0 diet. However, the highest plasma LDL-C level was observed in fish fed the $\mathrm{C} 15$ diet. The plasma LDL-C:HDL-C ratio was significantly decreased by dietary cholesterol supplementation, regardless of inclusion level.

\begin{tabular}{|c|c|c|c|c|c|c|c|c|c|c|c|c|}
\hline & \multicolumn{2}{|c|}{$\mathrm{CO}$} & \multicolumn{2}{|l|}{$\mathrm{C} 3$} & \multicolumn{2}{|c|}{ C6 } & \multicolumn{2}{|c|}{$\mathrm{C9}$} & \multicolumn{2}{|c|}{$\mathrm{C} 12$} & \multicolumn{2}{|c|}{ C15 } \\
\hline & Mean & SEM & Mean & SEM & Mean & SEM & Mean & SEM & Mean & SEM & Mean & SEM \\
\hline Initial weight (g) & 57.9 & 0.8 & $58 \cdot 0$ & 0.7 & 57.5 & 0.5 & 57.5 & 0.8 & $57 \cdot 2$ & 0.3 & $57 \cdot 8$ & 1.0 \\
\hline Final weight (g) & $177 \cdot 9^{a}$ & 1.5 & $181 \cdot 1^{a, b}$ & 0.7 & $188 \cdot 0^{\mathrm{b}, \mathrm{c}}$ & $2 \cdot 7$ & $193 \cdot 7^{\mathrm{C}}$ & 1.9 & $212 \cdot 2^{d}$ & $2 \cdot 0$ & $188 \cdot 0^{\mathrm{b}, \mathrm{c}}$ & $2 \cdot 6$ \\
\hline DGC (\%/d) & $2 \cdot 88^{\mathrm{a}}$ & 0.05 & $2 \cdot 93^{\mathrm{a}, \mathrm{b}}$ & 0.03 & $3.06^{b, c}$ & 0.04 & $3 \cdot 16^{c}$ & 0.02 & $3.43^{d}$ & 0.03 & $3 \cdot 05^{b, c}$ & 0.03 \\
\hline First week feed intake (g/fish) & $14 \cdot 80$ & 0.11 & $14 \cdot 80$ & 0.36 & $14 \cdot 88$ & 0.14 & $15 \cdot 24$ & 0.28 & $15 \cdot 56$ & 0.14 & 14.50 & 0.34 \\
\hline Feed intake (g/kg MBW per d) & 13.41 & 0.13 & 13.62 & 0.21 & 13.95 & 0.16 & 13.99 & 0.06 & $13 \cdot 62$ & 0.13 & 13.98 & 0.07 \\
\hline Feed efficiency & $0.75^{\mathrm{a}}$ & 0.01 & $0.75^{\mathrm{a}}$ & 0.01 & $0.75^{\mathrm{a}}$ & 0.02 & $0.78^{\mathrm{a}}$ & 0.01 & $0.86^{\mathrm{b}}$ & 0.01 & $0.76^{\mathrm{a}}$ & 0.01 \\
\hline Survival (\%) & $100 \cdot 0$ & $0 \cdot 0$ & $98 \cdot 1$ & $2 \cdot 0$ & $100 \cdot 0$ & $0 \cdot 0$ & $98 \cdot 1$ & $2 \cdot 0$ & $96 \cdot 3$ & $2 \cdot 0$ & 88.9 & $5 \cdot 6$ \\
\hline
\end{tabular}

Dietary cholesterol supplementation significantly increased hepatic total lipid content, regardless of inclusion level, and the highest value was observed in fish fed the C12 diet

Table 2. Feed intake, growth and feed efficiency of rainbow trout (Oncorhynchus mykiss) during the feeding period (Mean values with their standard errors, $n 3$ )

C0, basal diet; C3, 0.3\% cholesterol; C6, 0.6\% cholesterol; C9, 0.9\% cholesterol; C12, 1.2\% cholesterol; C15, 1.5\% cholesterol; DGC, daily growth coefficient; MBW, metabolic body weight.

a,b,c,d Mean values within a row with unlike superscript letters were significantly different $(P<0.05)$. 
Table 3. Proximate composition ( $\mathrm{g} / \mathrm{kg}$ wet weight) of the whole body of rainbow trout (Oncorhynchus mykiss) fed with diets containing different cholesterol levels

(Mean values with their standard errors, $n 3$ )

\begin{tabular}{|c|c|c|c|c|c|c|c|c|c|c|c|c|}
\hline & \multicolumn{2}{|c|}{$\mathrm{CO}$} & \multicolumn{2}{|c|}{$\mathrm{C} 3$} & \multicolumn{2}{|c|}{ C6 } & \multicolumn{2}{|c|}{$\mathrm{C9}$} & \multicolumn{2}{|c|}{$\mathrm{C} 12$} & \multicolumn{2}{|c|}{ C15 } \\
\hline & Mean & SEM & Mean & SEM & Mean & SEM & Mean & SEM & Mean & SEM & Mean & SEM \\
\hline Moisture & 721.4 & 5.9 & 721.5 & 8.3 & 713.4 & $7 \cdot 2$ & $715 \cdot 8$ & 1.0 & $700 \cdot 6$ & $4 \cdot 8$ & $710 \cdot 2$ & 8.0 \\
\hline Crude protein & $154 \cdot 6$ & $2 \cdot 4$ & $155 \cdot 0$ & $2 \cdot 8$ & $160 \cdot 5$ & 3.8 & 159.5 & $1 \cdot 2$ & $162 \cdot 9$ & $3 \cdot 1$ & $154 \cdot 8$ & 3.7 \\
\hline Crude lipid & $73 \cdot 3$ & 0.5 & $79 \cdot 0$ & $3 \cdot 8$ & $83 \cdot 2$ & 6.5 & $81 \cdot 7$ & $3 \cdot 0$ & $86 \cdot 5$ & $3 \cdot 1$ & $80 \cdot 1$ & 3.4 \\
\hline Ash & $24 \cdot 0$ & 0.6 & 23.4 & 0.2 & 23.6 & 0.1 & $23 \cdot 0$ & 0.5 & $22 \cdot 9$ & 0.5 & $23 \cdot 3$ & 0.4 \\
\hline
\end{tabular}

C0, basal diet; C3, 0.3\% cholesterol; C6, 0.6\% cholesterol; C9, 0.9\% cholesterol; C12, 1.2\% cholesterol; C15, $1.5 \%$ cholesterol.

(Table 4). Fish fed the C15 diet showed a significantly higher hepatic cholesterol content compared with those fed the C0 diet. The hepatic TAG level increased steadily when the supplemental cholesterol was increased by up to $0.9 \%$ and then declined with further addition.

Fish fed the C12 and C15 diets showed significantly higher muscle total lipid content compared with those fed the C0 and C3 diets (Table 4). However, muscle cholesterol content was significantly higher in fish fed the C6 and C9 diets compared with those fed the $\mathrm{C} 0$ and $\mathrm{C} 15$ diets. Muscle TAG content increased steadily when the supplemental cholesterol was increased by up to $0.9 \%$ and then reached a plateau.

Dietary cholesterol supplementation generally increased TC, FC, CE and TBA levels in the intestinal contents (Table 4). FC and TC levels in the intestinal contents increased steadily with increasing supplemental cholesterol. The CE level in the intestinal contents was significantly higher in fish fed the C6, C12 and C15 diets compared with those fed the C0 and C3 diets. Similarly, the FC:TC ratio in the intestinal contents were significantly higher in fish fed the high-cholesterol diets (C9, C12 and C15) compared with those fed the low-cholesterol diets (C0, C3 and C6). The TBA level in the intestinal contents increased steadily when the supplemental cholesterol was increased by up to $0.9 \%$ and then reached a plateau.

Plasma triiodothyronine, thyroxine, cortisol, calcium and phosphorus levels

Fish fed the C6, C9, C12 and C15 diets showed a significantly higher plasma $\mathrm{T}_{3}$ level compared with those fed the $\mathrm{C} 0$ diet (Table 5). The plasma Ca level was significantly higher in fish fed the C15 diet compared with those fed the C0, C3 and C9 diets. However, the plasma P level was significantly higher in fish fed the $\mathrm{C} 0$ diet compared with those fed the C3, C6 and C15 diets. No significant differences were observed in the plasma thyroxine and cortisol levels among the dietary treatments.

Hepatic acyl-CoA:cholesterol acyl transferase, 3-hydroxy3-methyl-glutaryl-CoA reductase and cholesterol

$7 \alpha$-hydroxylase activities

Low levels of dietary cholesterol supplementation (0.3-0.6\%) did not affect hepatic ACAT activity, but high levels of dietary cholesterol supplementation (0.9-1.5\%) significantly increased hepatic ACAT activity (Fig. 1). Dietary cholesterol supplementation significantly decreased the hepatic HMGR activity, regardless of inclusion level, and the decrease was most significant at $0 \cdot 3 \%$ supplemental cholesterol (Fig. 2). Similarly, low levels of dietary cholesterol supplementation (0.6-0.9\%) significantly decreased the hepatic CYP7A1 activity, but a high level of dietary cholesterol supplementation (1.5\%) significantly increased the hepatic CYP7A1 activity (Fig. 3).

\section{Discussion}

\section{Growth}

Replacing FM with SBM decreases the blood cholesterol level of fish, and the cholesterol-lowering effect of SBM is positively associated with its growth-depressing action ${ }^{(2,8,9)}$. Cholesterol, a vital component of cell membranes and the precursor of bile acids, steroid and hormones, is essential for diverse cellular functions ${ }^{(32)}$. Thus, cholesterol supplementation may be required as plant-derived protein sources (such as SBM, cottonseed meal and rapeseed meal) become the main protein source in fish feeds ${ }^{(4,5,19)}$. In the present study, dietary cholesterol supplementation $(0 \cdot 6-1.5 \%)$ significantly increased the DGC of rainbow trout fed a SBM-based diet containing $0 \cdot 38 \%$ cholesterol, and the maximum DGC was observed in fish fed a diet supplemented with $1 \cdot 2 \%$ cholesterol. Similar results were reported in studies on channel catfish (Ictalurus punctatus $^{(17)}$, Japanese flounder (Paralichthys olivaceus) ${ }^{(18)}$ and turbot (Scophthalmus maximus) $)^{(18,20)}$ fed soya-based diets. However, the growth-promoting effect of dietary cholesterol was not observed in Atlantic salmon (Salmo salar) ${ }^{(33)}$, hybrid striped bass (Morone chrysops $\times$ M. saxatilis) ${ }^{(34)}$ and Japanese flounder ${ }^{(18)}$ fed FM-based diets and in channel catfish $^{(17)}$ fed casein-based diets. These results indicate that dietary cholesterol supplementation may alleviate the negative effects of SBM; the underlying mechanism will be discussed later.

In the present study, fish were not pair-fed, as feed intakes were not expected to be different among the dietary treatments. Previous studies reported that dietary cholesterol level did not make an impact on feed consumption of chickens using a two-choice preference test ${ }^{(22,23)}$ and feed intake (expressed as $\mathrm{g} / \mathrm{kg}$ MBW per d) of Japanese flounder ${ }^{(18)}$. Similar results were also observed in the present study. Dietary 
Table 4. Lipid profiles in plasma, liver, muscle and intestinal contents in rainbow trout (Oncorhynchus mykiss) fed diets with different cholesterol levels (Mean values with their standard errors, $n 3$ )

\begin{tabular}{|c|c|c|c|c|c|c|c|c|c|c|c|c|}
\hline & \multicolumn{2}{|c|}{$\mathrm{CO}$} & \multicolumn{2}{|c|}{ C3 } & \multicolumn{2}{|c|}{ C6 } & \multicolumn{2}{|c|}{$\mathrm{C} 9$} & \multicolumn{2}{|c|}{$\mathrm{C} 12$} & \multicolumn{2}{|c|}{$\mathrm{C} 15$} \\
\hline & Mean & SEM & Mean & SEM & Mean & SEM & Mean & SEM & Mean & SEM & Mean & SEM \\
\hline \multicolumn{13}{|l|}{ Plasma (mmol/l) } \\
\hline TAG & $3.87^{a, b}$ & 0.27 & $3.09^{a}$ & 0.17 & $3.32^{a}$ & 0.05 & $5.42^{\mathrm{b}}$ & 0.48 & $2.75^{\mathrm{a}}$ & 0.39 & $3.55^{\mathrm{a}}$ & 0.52 \\
\hline Total cholesterol & $9 \cdot 20^{\mathrm{a}}$ & 0.21 & $8.29^{\mathrm{a}}$ & 0.63 & $9 \cdot 32^{\mathrm{a}}$ & 0.18 & $15 \cdot 52^{\mathrm{b}}$ & 0.47 & $20 \cdot 28^{\mathrm{c}}$ & 1.32 & $21 \cdot 61^{\mathrm{c}}$ & 1.84 \\
\hline HDL-cholesterol & $0.11^{\mathrm{a}}$ & 0.03 & $2.09^{\mathrm{b}}$ & 0.42 & $1.66^{\mathrm{b}}$ & 0.14 & $3.49^{\mathrm{c}}$ & 0.27 & $8.00^{\mathrm{d}}$ & 0.21 & $2 \cdot 55^{b, c}$ & 0.31 \\
\hline LDL-cholesterol & $8 \cdot 32^{a, b, c}$ & 0.22 & $5.58^{\mathrm{a}}$ & 0.26 & $6.99^{a, b}$ & 0.26 & $10.94^{b, c}$ & 0.30 & $11.73^{\mathrm{c}}$ & 1.34 & $18 \cdot 35^{\mathrm{d}}$ & 1.69 \\
\hline LDL-cholesterol:HDL-cholesterol & $90 \cdot 95^{\mathrm{b}}$ & $2 \cdot 86$ & $2 \cdot 87^{\mathrm{a}}$ & 0.51 & $4 \cdot 30^{\mathrm{a}}$ & 0.48 & $3 \cdot 17^{\mathrm{a}}$ & 0.28 & $1.47^{\mathrm{a}}$ & 0.18 & $7 \cdot 29^{\mathrm{a}}$ & 0.54 \\
\hline \multicolumn{13}{|l|}{ Liver (mg/g wet matter) } \\
\hline Total lipids & $11 \cdot 22^{\mathrm{a}}$ & 0.43 & $30.44^{\mathrm{b}}$ & 0.72 & $26 \cdot 85^{\mathrm{b}}$ & $2 \cdot 30$ & $27 \cdot 27^{\mathrm{b}}$ & 1.25 & $39 \cdot 30^{c}$ & $2 \cdot 28$ & $26 \cdot 54^{\mathrm{b}}$ & 1.05 \\
\hline Cholesterol & $0.20^{\mathrm{a}}$ & 0.03 & $0.26^{a, b}$ & 0.02 & $0.27^{a, b}$ & 0.02 & $0.28^{a, b}$ & 0.01 & $0 \cdot 24^{a, b}$ & 0.01 & $0.29^{b}$ & 0.01 \\
\hline TAG & $5.97^{\mathrm{a}}$ & 1.04 & $10 \cdot 36^{a, b}$ & 1.42 & $13 \cdot 49^{b, c}$ & 1.31 & $15 \cdot 39^{c}$ & 0.18 & $14 \cdot 21^{\mathrm{b}, \mathrm{c}}$ & 0.84 & $10 \cdot 39^{a, b}$ & 0.81 \\
\hline \multicolumn{13}{|l|}{ Muscle ( $\mathrm{g} / \mathrm{kg}$ wet matter) } \\
\hline Total lipids & $40 \cdot 61^{a}$ & 0.72 & $40 \cdot 37^{\mathrm{a}}$ & $1 \cdot 37$ & $43 \cdot 36^{a, b}$ & 0.97 & $44 \cdot 44^{\mathrm{a}, \mathrm{b}}$ & 1.81 & $46 \cdot 85^{\mathrm{b}}$ & 1.54 & $46 \cdot 15^{\mathrm{b}}$ & 1.39 \\
\hline Cholesterol & $0.57^{\mathrm{a}}$ & 0.00 & $0.64^{a, b}$ & 0.04 & $0.87^{c}$ & 0.04 & $0.84^{b, c}$ & 0.04 & $0.72^{\mathrm{a}, \mathrm{b}, \mathrm{c}}$ & 0.06 & $0.62^{\mathrm{a}}$ & 0.06 \\
\hline TAG & $22 \cdot 77^{\mathrm{a}}$ & 1.20 & $23 \cdot 37^{\mathrm{a}}$ & 1.31 & $27 \cdot 75^{a, b}$ & 0.17 & $31.53^{b}$ & 1.59 & $30 \cdot 14^{b}$ & $2 \cdot 11$ & $30 \cdot 18^{\mathrm{b}}$ & 1.20 \\
\hline \multicolumn{13}{|l|}{ Intestinal contents } \\
\hline Total cholesterol (mmol/g DM) & $0.08^{\mathrm{a}}$ & 0.01 & $0.11^{\mathrm{a}}$ & 0.02 & $0.54^{\mathrm{b}}$ & 0.05 & $0.60^{\mathrm{b}, \mathrm{c}}$ & 0.04 & $0.92^{\mathrm{c}}$ & 0.13 & $1.47^{\mathrm{d}}$ & 0.12 \\
\hline Free cholesterol (mmol/g DM) & $0.03^{\mathrm{a}}$ & 0.01 & $0.04^{\mathrm{a}}$ & 0.00 & $0.13^{\mathrm{a}}$ & 0.00 & $0.39^{\mathrm{b}}$ & 0.01 & $0.54^{\mathrm{b}}$ & 0.04 & $1.08^{\mathrm{c}}$ & 0.12 \\
\hline Cholesteryl esters (mmol/g DM) & $0.05^{\mathrm{a}}$ & 0.00 & $0.08^{\mathrm{a}}$ & 0.01 & $0.42^{\mathrm{b}}$ & 0.05 & $0.21^{a, b}$ & 0.04 & $0.38^{\mathrm{b}}$ & 0.11 & $0.39^{\mathrm{b}}$ & 0.05 \\
\hline Free cholesterol:total cholesterol & $0.31^{\mathrm{a}}$ & 0.02 & $0.33^{\mathrm{a}}$ & 0.01 & $0.24^{\mathrm{a}}$ & 0.03 & $0.66^{\mathrm{b}}$ & 0.05 & $0.60^{\mathrm{b}}$ & 0.07 & $0.73^{\mathrm{b}}$ & 0.04 \\
\hline Total bile acids (mmol/g DM) & $0.67^{\mathrm{a}}$ & 0.02 & $1 \cdot 19^{\mathrm{a}, \mathrm{b}}$ & 0.01 & $1 \cdot 22^{a, b}$ & 0.04 & $1.52^{\mathrm{b}}$ & 0.18 & $1.35^{\mathrm{b}}$ & 0.08 & $1.64^{\mathrm{b}}$ & 0.16 \\
\hline
\end{tabular}

C0, basal diet; C3, 0.3\% cholesterol; C6, 0.6\% cholesterol; C9, $0.9 \%$ cholesterol; C12, $1.2 \%$ cholesterol; C15, $1.5 \%$ cholesterol.

a,b,c,d Mean values within a row with unlike superscript letters are significantly different $(P<0.05)$. 
Table 5. Plasma triiodothyronine, thyroxine, cortisol, calcium and phosphorus contents in the plasma of rainbow trout (Oncorhynchus mykiss) fed diets with different cholesterol levels

(Mean values with their standard errors, $n 3$ )

\begin{tabular}{|c|c|c|c|c|c|c|c|c|c|c|c|c|}
\hline & \multicolumn{2}{|c|}{$\mathrm{CO}$} & \multicolumn{2}{|c|}{$\mathrm{C} 3$} & \multicolumn{2}{|c|}{ C6 } & \multicolumn{2}{|c|}{$\mathrm{Cg}$} & \multicolumn{2}{|c|}{$\mathrm{C} 12$} & \multicolumn{2}{|c|}{ C15 } \\
\hline & Mean & SEM & Mean & SEM & Mean & SEM & Mean & SEM & Mean & SEM & Mean & SEM \\
\hline Triiodothyronine $(\mathrm{ng} / \mathrm{ml})$ & $4 \cdot 14^{\mathrm{a}}$ & 0.13 & $4 \cdot 67^{a, b}$ & $0 \cdot 12$ & $5 \cdot 59^{b}$ & 0.17 & $5 \cdot 59^{b}$ & 0.42 & $5 \cdot 67^{b}$ & 0.32 & $5 \cdot 28^{b}$ & 0.28 \\
\hline Thyroxine $(\mathrm{ng} / \mathrm{ml})$ & $5 \cdot 39$ & 0.16 & 5.92 & 0.37 & $6 \cdot 30$ & 0.50 & $7 \cdot 14$ & 0.42 & 7.05 & 0.40 & $7 \cdot 28$ & 0.69 \\
\hline Cortisol (ng/ml) & 5.53 & 0.28 & 4.95 & 0.47 & 4.35 & 0.24 & 4.73 & 0.19 & 4.58 & 0.26 & 5.58 & 0.46 \\
\hline $\mathrm{Ca}(\mathrm{mmol} / \mathrm{l})$ & $2 \cdot 71^{a}$ & 0.23 & $3 \cdot 13^{a}$ & 0.16 & $3 \cdot 36^{a, b}$ & 0.09 & $3 \cdot 21^{a}$ & 0.18 & $3 \cdot 40^{\mathrm{a}, \mathrm{b}}$ & 0.16 & $4.03^{b}$ & 0.12 \\
\hline $\mathrm{P}(\mathrm{mmol} / \mathrm{l})$ & $5 \cdot 63^{b}$ & 0.06 & $4.06^{a}$ & 0.21 & $4 \cdot 38^{a}$ & 0.24 & $4 \cdot 87^{\mathrm{a}, \mathrm{b}}$ & 0.36 & $4.54^{\mathrm{a}, \mathrm{b}}$ & 0.38 & $4 \cdot 24^{a}$ & 0.21 \\
\hline
\end{tabular}

C0, basal diet; C3, 0.3\% cholesterol; C6, 0.6\% cholesterol; C9, 0.9\% cholesterol; C12, $1.2 \%$ cholesterol; C15, $1.5 \%$ cholesterol.

${ }_{\mathrm{a}, \mathrm{b}}$ Mean values within a row with unlike superscript letters were significantly different $(P<0.05)$.

cholesterol supplementation did not affect the first week feed intake ( $\mathrm{g} / \mathrm{fish}$ ) and total feed intake ( $\mathrm{g} / \mathrm{kg} \mathrm{MBW}$ per $\mathrm{d}$ ), regardless of inclusion level (Table 2), which indicates that dietary cholesterol does not affect the feed palatability, and the apparent increase in feed consumption may be primarily attributed to the large fish size at the later stage. Thus, we deem that the effects on growth rate are primarily due to the diet composition (i.e. the incremental level of cholesterol) other than the feed intake in the present study.

\section{Cholesterol metabolism and homeostasis}

The hypocholesterolaemic effect of SBM compared with FM is well documented in fish ${ }^{(2,9)}$. At present, information on cholesterol metabolism in fish is limited ${ }^{(35)}$. Blood cholesterol level is the result of dietary cholesterol (exogenous cholesterol) and de novo cholesterol synthesis in the liver (endogenous cholesterol). In the present study, low levels of supplemental cholesterol $(0.3-0.6 \%)$ do not affect the plasma TC level, which indicates that SBM partially alleviates the negative effects of supplemental cholesterol on plasma TC. This observation is in accordance with that by Chen ${ }^{(36)}$, who reported that $0.5 \%$ cholesterol supplementation did not affect the plasma TC level in Japanese flounder fed SBM-based diets. Our previous studies also showed that the plasma TC level of Japanese flounder is unaffected by supplementation with $1 \%$ cholesterol in soya protein concentrate-based or soya protein isolate-based diets ${ }^{(18)}$. Furthermore, several studies with fish revealed that soya protein concentrate has cholesterol-lowering effects compared with soya protein isolate, and raw SBM compared with purified SBM or soya protein concentrate ${ }^{(6,18)}$. Thus, several studies insisted that the hypocholesterolaemic effect of SBM might be related to non-protein compounds, such as the wide range of phytochemicals present in SBM, but absent in $\mathrm{FM}^{(37,38)}$. On the other hand, the present study also shows that high levels of supplemental cholesterol (0.9-1.5\%) significantly increase the plasma TC levels of rainbow trout. Similar results were observed in studies on Japanese floun$\operatorname{der}^{(36)}$, yellowtail (Seriola quinqueradiata) ${ }^{(15)}$ and turbot ${ }^{(19)}$. The blood TC levels of these fish were increased to levels comparable with fish fed FM-based diets, but the actual cholesterol content was apparently higher in SBM-based diets with supplemental cholesterol (1.07-1.78\%) compared with FM-based diets $(0.29-0.63 \%)$. Thus, we suggest that the hypocholesterolaemia in fish induced by replacing FM with high levels of SBM may be related to both insufficient dietary cholesterol and a decrease in endogenous cholesterol.

Cholesterol homeostasis is achieved by regulating cholesterol uptake, cholesterol biosynthesis, cholesterol conversion to bile acids and excretion of bile acids. The absorption of dietary cholesterol from the intestines is an important part of cholesterol homeostasis and represents the first step that allows dietary cholesterol to exert its metabolic effects ${ }^{(39)}$. The major form of dietary cholesterol is FC (unesterified form of cholesterol), and CE is not absorbed as is but must be hydrolysed into FC by pancreatic enzymes before uptake $^{(40)}$. In the present study, dietary cholesterol supplementation causes a linear increase in the FC and TC levels in the intestinal contents. However, the FC:TC ratio is markedly lower in the fish fed diets containing lower cholesterol levels (C0, C3 and C6) compared with those fed diets containing higher cholesterol levels (C9, C12 and C15). This result indicates that the non-protein compounds present in SBM inhibited cholesterol absorption by interfering with the hydrolysis of $\mathrm{CE}$ in the intestines. Previous studies involving fish also showed that non-protein compounds (such as saponins, fibre and NSP) with particularly defined structural characteristics form insoluble complexes with cholesterol, thereby decreasing the absorption of both endogenous and exogenous cholesterol ${ }^{(41-43)}$. After absorption, FC and fatty

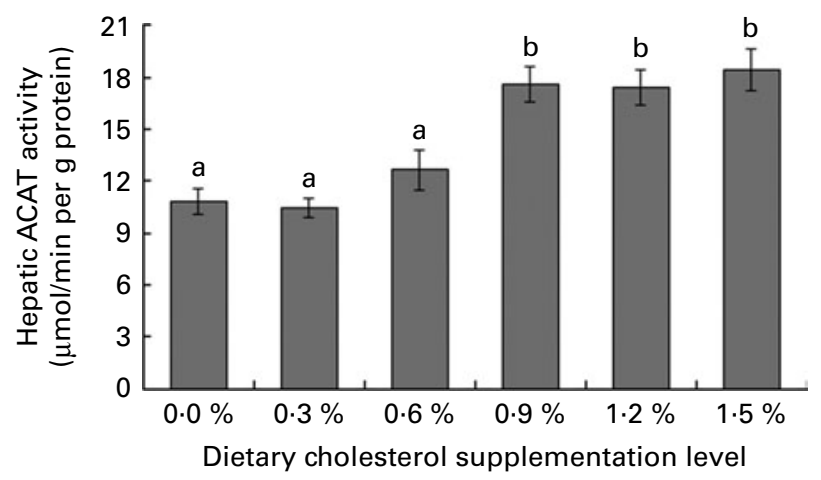

Fig. 1. Hepatic acyl-CoA:cholesterol acyl transferase (ACAT) activity in rainbow trout (Oncorhynchus mykiss) fed with diets containing different cholesterol levels. Values are means, with their standard errors represented by vertical bars ( $n 3)$. ${ }^{\mathrm{a}, \mathrm{b}}$ Mean values with unlike letters were significantly different $(P<0.05)$. 


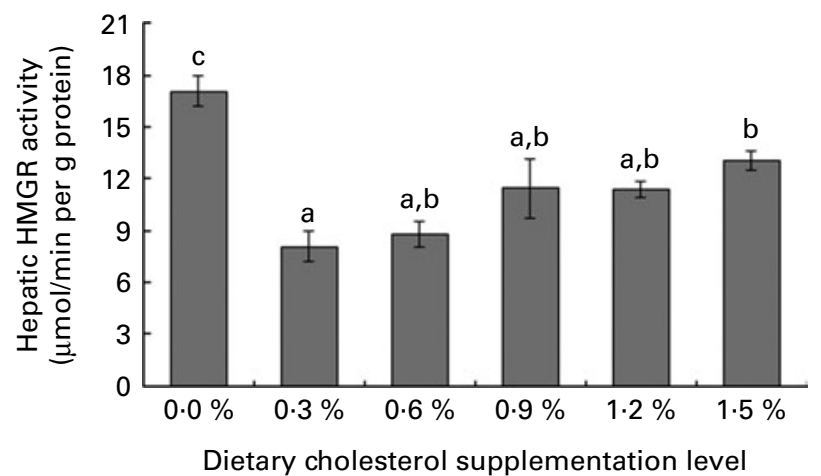

Fig. 2. Hepatic 3-hydroxy-3-methyl-glutaryl-CoA reductase (HMGR) activity in rainbow trout (Oncorhynchus mykiss) fed with diets containing different cholesterol levels. Values are means, with their standard errors represented by vertical bars $(n 3) .{ }^{a, b, c}$ Mean values with unlike letters were significantly different $(P<0.05)$.

acids are re-esterified in enterocytes by ACAT ${ }^{(39)}$. High levels of cholesterol supplementation significantly improved the hepatic microsomal ACAT activity in the present study, which is consistent with in vivo studies on chicks ${ }^{(44)}$, pigs ${ }^{(45)}$ and rats ${ }^{(46)}$. The in vitro addition of cholesterol to microsomal fractions significantly increases ACAT activity ${ }^{(47,48)}$. These results indicate that non-protein compounds present in SBM may interfere with the intestinal absorption of cholesterol, while redundant cholesterol from exogenous supplementation (i.e. unbound cholesterol in the intestinal contents) may be absorbed if available.

Cholesterol biosynthesis is controlled by a feedback mechanism with HMGR as the key enzyme. HMGR, an endoplasmic reticulum-bound enzyme, catalyses the rate-limiting step in cholesterol synthesis ${ }^{(49)}$. Although HMGR is found in all tissues, it is highly expressed in the liver ${ }^{(50)}$, wherein the cholesterol feedback regulation of HMGR mainly occurs ${ }^{(51)}$. Thus, the feedback regulation of hepatic HMGR activity or mRNA level contributes to the overall cholesterol homeostasis ${ }^{(50,52)}$. The present study shows that low levels of supplemental cholesterol $(0.3-0.6 \%)$ markedly decreases hepatic HMGR activity, but does not affect the hepatic and plasma cholesterol contents. This result indicates that the decreased hepatic HMGR activity in response to the increased cholesterol that reaches the liver via chylomicron remnants provides an effective means of maintaining desirable cholesterol levels ${ }^{(50)}$. However, the hepatic HMGR activity is not further decreased by higher levels of supplemental cholesterol (0.9-1.5\%), thereby increasing plasma cholesterol levels. These results indicate that rainbow trout has a certain 'cholesterol-buffering capacity', which protects the body against increased serum cholesterol levels caused by dietary cholesterol. The 'cholesterol-buffering capacity' implies the possibility of the inhibition of exogenous cholesterol absorption and/or inadequate endogenous production of cholesterol in rainbow trout fed SBM-based diets.

Cholesterol metabolism into bile acids in the liver represents the major route for cholesterol clearance ${ }^{(53)}$. Bile acids synthesised in the liver are immediately secreted into the bile, reabsorbed in the intestines and transported back to the liver. CYP7A1 is the first and the rate-limiting enzyme of the classical neutral pathway for bile acid synthesis ${ }^{(54)}$, and its activity is regulated by the flux of cholesterol through the liver and the return of bile acids via the enterohepatic circulation ${ }^{(55)}$. The present study shows that low levels of supplemental cholesterol $(0 \cdot 3-0 \cdot 9 \%)$ generally increase bile acid concentration in the intestinal contents, but decrease hepatic CYP7A1 activity. This result indicates that low levels of supplemental cholesterol inhibit cholesterol catabolism. However, hepatic CYP7A1 activity was markedly increased by high levels of cholesterol supplementation (1.5\%), which is consistent with studies involving rats ${ }^{(46)}$. These results indicate that high levels of dietary cholesterol promote the cholesterol catabolic pathway ${ }^{(46,55)}$. Unfortunately, the faecal rate of cholesterol excretion was not determined because faecal samples were not collected.

Similar to that in mammals, fish lipoproteins are classified as VLDL, intermediate-density lipoprotein, LDL and $\mathrm{HDL}^{(56)}$. LDL carries cholesterol from the liver to the peripheral tissues, whereas HDL carries cholesterol from the peripheral tissues to the liver. Thus, the LDL-C:HDL-C ratio could be used as a marker of cholesterol transport ${ }^{(18,19)}$. In the present study, dietary cholesterol supplementation markedly depressed the plasma LDL-C:HDL-C ratio in fish fed SBM-based diets, regardless of inclusion levels. Similarly, previous studies also showed that dietary cholesterol supplementation (1.0-1.5\%) decreased the plasma LDL-C:HDL-C ratio in fish fed soya protein-based diets ${ }^{(18-20)}$. These results indicate that supplemental cholesterol may increase the ability of carrying cholesterol from peripheral tissues to the liver in fish fed soya product-based diets. By contrast, dietary cholesterol supplementation markedly increases the plasma LDL-C:HDL-C ratio in fish fed FM-based diets ${ }^{(33)}$. These results indicate that dietary cholesterol and protein sources affect the distribution of cholesterol among plasma lipoproteins ${ }^{(18)}$.

Thyroid hormones and their activities are deemed as good biological markers of growth capacity in fish ${ }^{(57)}$. A low plasma concentration of $\mathrm{T}_{3}$, the biologically active hormone, is indicative of metabolic disruption expressed by poor growth $^{(58)}$. In the present study, dietary cholesterol content markedly influenced the plasma $\mathrm{T}_{3}$ level, and a good

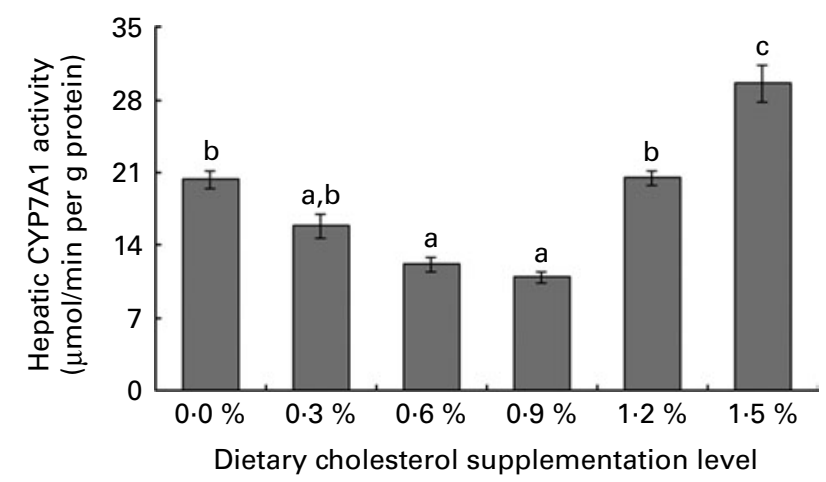

Fig. 3. Hepatic cholesterol $7 \alpha$-hydroxylase (CYP7A1) activity in rainbow trout (Oncorhynchus mykiss) fed with diets containing different cholesterol levels. Values are means, with their standard errors represented by vertical bars $(n 3)$. ${ }^{a, b, c}$ Mean values with unlike letters were significantly different $(P<0.05)$. 
correlation $(r 0.670, P<0.01)$ between plasma $\mathrm{T}_{3}$ level and DGC in fish was observed. Similarly, many studies have shown a close relationship between growth rate and plasma $\mathrm{T}_{3}$ level in fish ${ }^{(59,60)}$. Cortisol, a potent gluco- and mineralocorticoid in teleosts, is involved in the regulation of metabolism and growth in fish ${ }^{(61)}$. Plasma cortisol, the most commonly measured indicator of stress, has a negative-feedback effect on growth of fish ${ }^{(62)}$. The present study shows that there is a negative relationship $(r=-0.554, \quad P<0.05)$ between plasma cortisol level and DGC of fish. Vitamin D, the chief nutrient and hormone regulator of body $\mathrm{Ca}$ and $\mathrm{P}$ metabolism, originates from 7-dehydrocholesterol of vertebrates. Thus, cholesterol is necessary for $\mathrm{Ca}$ and $\mathrm{P}$ metabolism ${ }^{(63)}$. In the present study, dietary cholesterol levels significantly affect the plasma Ca level $(r 0.743, P<0.01)$, and serum cholesterol is positively related to serum Ca levels $(r 0.627, P<0.01)$. Similar results have been reported in fish ${ }^{(64)}$, rats ${ }^{(65)}$ and chickens $^{(66)}$. These results indicate that one of the hypercholesterolaemic actions of dietary cholesterol is to induce an increase in plasma $\mathrm{Ca}$ concentrations ${ }^{(63,65)}$, which may be related to (1) the alteration of the membrane fluidity, (2) the increase in surface area resulting from the insertion of cholesterol into the membrane and (3) the interaction between cholesterol and the proteins of the $\mathrm{Ca}^{2+}$ channel and of the $\mathrm{Ca}^{2+}$ pump ${ }^{(63)}$.

Blood cholesterol is generally expected to increase in response to dietary cholesterol ${ }^{(16)}$. However, the plasma TC level was not different among fish fed the C0, C3 and C6 diets in the present study. The lack of response may have occurred because the animals do not absorb the available dietary cholesterol, catabolise or excrete the absorbed exogenous cholesterol or clear the absorbed exogenous cholesterol from the circulation by depositing it in cellular membranes and tissues associated with the increased body tissue accretion ${ }^{(16)}$. Cholesterol is found to interact with saponins to form insoluble sterol-saponin compounds in the intestine, which no longer possess toxic and haemolytic properties ${ }^{(22,67)}$, and to reduce the phytosterol (e.g. $\beta$-sitosterol, stigmasterol and campesterol) concentration in the intestinal mixed micelles via a dynamic competition mechanism, resulting in increased excretion of phytosterol ${ }^{(68)}$. In addition, our previous study showed that cholesterol might interact in vitro with tannins, pectin and $\beta$-glucan to form insoluble compounds ( $\mathrm{J}$ Deng, $\mathrm{X}$ Long and $\mathrm{X}$ Zhang, unpublished results). Thus, cholesterol supplementation has been found to alleviate the negative effects of dietary soya saponins and soya isoflavones ${ }^{(22,67)}$. These results imply that dietary cholesterol supplementation could partially alleviate the deleterious effects of non-protein components present in soya products, but the exact mechanism by which this occurs needs further elucidation.

The increased dietary cholesterol level (from 0.3 to $0.9 \%$ ) appears to have compensated for the impaired hepatic CYP7A1 activity, as the TBA level in the intestinal contents continues to increase with increasing supplemental cholesterol level up to $0.9 \%$. The increased TBA level in the intestinal contents will contribute to improvement in lipase activity and lipid digestibility ${ }^{(36)}$, and thereby promote the total lipid depositions in the muscle and liver of rainbow trout ${ }^{(18,19)}$.
The elevated muscle and hepatic total lipid depositions indicate increased energy reserves that could potentially result in improved growth performance of rainbow trout fed SBM-based diets. In addition, the growth-promoting effect of dietary cholesterol is associated with the cholesterolstimulating action when the supplemental cholesterol is increased by up to $0.9 \%$, which suggests the possibility that inadequate endogenously produced cholesterol might be limiting normal growth of rainbow trout fed SBM-based diets ${ }^{(16)}$. Thus, the growth-promoting action of dietary cholesterol seems to compensate partially for the inadequate endogenously produced cholesterol activity ${ }^{(16)}$. However, in agreement with previous studies with fish ${ }^{(19,36)}$, the present study also shows that DGC is significantly lower in fish fed the C15 diet compared with fish fed the $\mathrm{C} 12$ diet, which indicates that excessive cholesterol inclusion may retard the growth of rainbow trout. Previous studies have demonstrated that cholesterol-rich diets induce the endothelial dysfunction and coronary atherosclerosis in salmon ${ }^{(69)}$. Thus, the impaired growth of rainbow trout fed the $\mathrm{C} 15$ diet is probably due to the dysfunction of cholesterol metabolism, but the exact mechanisms need further investigation.

In summary, data from the present study suggest the possibility of inadequate endogenous production of cholesterol in rainbow trout fed SBM-based diets. The growth-promoting effects of dietary cholesterol supplementation (0.6-1.2\%) may be related to alleviation of the negative effects of SBM and/or make up for the deficiency of cholesterol in rainbow trout. However, the underlying mechanism remains unclear and needs to be determined in future studies.

\section{Acknowledgements}

The present research was financially supported by the National Natural Science Foundation of China (grant no. 30960298, 31160533 and 31260639). The authors thank Xiaowen Long for help in feeding and sampling. The contribution of the authors to the present paper is as follows: X. Z. developed the principal design of the study. J. D. contributed to the more detailed planning and was the main author during the preparation of the manuscript. B. B., Q. W. and L. K. performed the practical part of the study and participated in the data analyses. B. K. provided inputs on the trial design and methodology. All the authors had inputs during the writing of the manuscript. The authors declare no conflicts of interest.

\section{References}

1. Gatlin DM III, Barrows FT, Brown P, et al. (2007) Expanding the utilization of sustainable plant products in aquafeeds: a review. Aquacult Res 38, 551-579.

2. Lim SJ, Kim SS, Ko GY, et al. (2011) Fish meal replacement by soybean meal in diets for Tiger puffer, Takifugu rubripes. Aquaculture 313, 165-170.

3. Peres H, Lim C \& Klesius PH (2003) Nutritional value of heattreated soybean meal for channel catfish (Ictalurus punctatus). Aquaculture 225, 67-82.

4. Bureau DP (2007) Fish meal replacement in aquaculture feeds: opportunities for rendered products. Render $\mathbf{8}, 10-12$. 
5. Tocher DR, Bendiksen EA, Campbell PJ, et al. (2008) The role of phospholipids in nutrition and metabolism of teleost fish. Aquaculture 280, 21-34.

6. Hossain MA, Focken U \& Becker K (2001) Effect of soaking and soaking followed by autoclaving of Sesbania seeds on growth and feed utilisation in common carp, Cyprinus carpio L. Aquaculture 203, 133-148.

7. Deng JM, Mai KS, Ai QH, et al. (2012) Effects of antinutritional factors on plasma lipoprotein levels in Japanese flounder Paralichthys olivaceus. J Fish Biol 80, 286-300.

8. Sagstad A, Sanden M, Krogdahl A, et al. (2008) Organs development, gene expression and health of Atlantic salmon (Salmo salar L.) fed genetically modified soybeans compared to the near-isogenic non-modified parental line. Aquacult Nutr 14, 556-572.

9. Kader MA, Koshio S, Ishikawa M, et al. (2011) Growth, nutrient utilization, oxidative condition, and element composition of juvenile red sea bream Pagrus major fed with fermented soybean meal and scallop by-product blend as fishmeal replacement. Fish Sci 77, 119-128.

10. Vilhelmsson OT, Martin SAM, Médale F, et al. (2004) Dietary plant-protein substitution affects hepatic metabolism in rainbow trout (Oncorbynchus mykiss). Br J Nutr 92, 71-80.

11. Geay F, Ferraresso S, Zambonino-Infante JL, et al. (2011) Effects of the total replacement of fish-based diet with plant-based diet on the hepatic transcriptome of two European sea bass (Dicentrarchus labrax) half-sibfamilies showing different growth rates with the plant-based diet. $B M C$ Genomics 12, 522.

12. Russell DW (1992) Cholesterol biosynthesis and metabolism. Cardiovasc Drugs Ther 6, 103-110.

13. Hansen AC, Karlsen $\varnothing$, Rosenlund G, et al. (2007) Dietary plant protein utilization in Atlantic cod, Gadus morbus L. Aquacult Nutr 13, 200-215.

14. Maita M, Satoh K, Fukuda Y, et al. (1998) Correlation between plasma component levels of cultured fish and resistance to bacterial infection. Fish Pathol 33, 129-133.

15. Maita M, Maekawa J, Satoh K, et al. (2006) Disease resistance and hypocholesterolemia in yellowtail Seriola quinqueradiata fed a non-fishmeal diet. Fish Sci 72, 513-519.

16. Schoknecht PA, Ebner S, Pond WG, et al. (1994) Dietary cholesterol supplementation improves growth and behavioural response of pigs selected for genetically high and low serum cholesterol. J Nutr 124, 305-314.

17. Twibell RG \& Wilson RP (2004) Preliminary evidence that cholesterol improves growth and feed intake of soybean meal-based diets in aquaria studies with juvenile channel catfish, Ictalurus punctatus. Aquaculture 236, 539-546.

18. Deng J, Mai K, Ai Q, et al. (2010) Interactive effects of dietary cholesterol and protein sources on growth performance and cholesterol metabolism of Japanese flounder (Paralichthys olivaceus). Aquacult Nutr 16, 419-429.

19. Yun B, Mai K, Zhang W, et al. (2011) Effects of dietary cholesterol on growth performance, feed intake and cholesterol metabolism in juvenile turbot (Scophthalmus maximus L.) fed high plant protein diets. Aquaculture 319, 105-110.

20. Yun B, Ai Q, Mai K, et al. (2012) Synergistic effects of dietary cholesterol and taurine on growth performance and cholesterol metabolism in juvenile turbot (Scophthalmus maximus L.) fed high plant protein diets. Aquaculture 324-325, 85-91.

21. Deng J, Zhang X, Bi B, et al. (2011) Dietary protein requirement of juvenile Asian red-tailed catfish Hemibagrus wyckioides. Anim Feed Sci Technol 170, 231-238.

22. Ueda H \& Shigemizu G (2001) Feeding response to tea saponin in chicks given diet selection. J Poult Sci 38, 333-342.
23. Ueda H \& Suehiro K (2005) Feeding behaviour in chicks given the same diet simultaneously by two feeders: rightand left-handed chicks. J Poult Sci 42, 182-192.

24. Association of Official Analytical Chemists (1995) Official Methods of Analysis of Official Analytical Chemists International, 16th ed. Washington, DC: Association of Official Analytical Chemists.

25. Brett JR \& Groves TDD (1979) Physiological energetics. In Fish Physiology, vol. 8, pp. 280-351 [WS Hoar, DJ Randall and JR Brett, editors]. New York, NY: Academic Press.

26. Friedewald WT, Levy RI \& Fredrickson DS (1972) Estimation of the concentration of low-density lipoprotein cholesterol in plasma, without use of the preparative ultracentrifuge. Clin Chem 18, 499-502.

27. Folch J, Lees M \& Sloane Stanley GH (1957) A simple method for the isolation and purification of total lipides from animal tissues. J Biol Chem 226, 497-509.

28. Martinez I, Dreyer B, Argersborg A, et al. (1995) Effect of $\mathrm{T}_{3}$ and rearing temperature on growth and skeletal myosin heavy chain isoform transition during early development in salmonid Salvelinus alpinus (L.). Comp Biochem Physiol 112B, 717-725.

29. Metz JR, Geven EJW, van den Burg EH, et al. (2005) ACTH, $\alpha$-MSH and control of cortisol release: cloning, sequencing and functional expression of the melanocortin-2 and melanocortin-5 receptor in Cyprinus carpio. Am J Physiol 289, R814-R826.

30. Rasmussen MK, Ekstrand B \& Zamaratskaia G (2011) Comparison of cytochrome $\mathrm{P} 450$ concentrations and metabolic activities in porcine hepatic microsomes prepared with two different methods. Toxicol In Vitro 25, 343-346.

31. Bradford MM (1976) A rapid and sensitive method for the quantification of microgram quantities of proteins utilizing the principle of protein-dye binding. Anal Biochem $\mathbf{7 2}$, $248-254$.

32. Thomas J, Shentu TP \& Singh DK (2012) Cholesterol: biosynthesis, functional diversity, homeostasis and regulation by natural products. In Biochemistry, pp. 419-441 [D Ekinci, editor]. New York: In Tech. http://www.intechopen. com/books/biochemistry/cholesterol-biosynthesis-functionaldiversity-homeostasis-and-regulation-by-natural-products

33. Bjerkeng B, Storebakken T \& Wathne E (1999) Cholesterol and short-chain fatty acids in diets for Atlantic salmon Salmo salar (L.): effects on growth, organ indices, macronutrient digestibility, and fatty acid composition. Aquacult Nutr 5, $181-191$.

34. Sealey WM, Craig SR \& Gatlin DM III (2001) Dietary cholesterol and lecithin have limited effects on growth and body composition of hybrid striped bass (Morone chrysops $\times M$. saxatilis). Aquacult Nutr 7, 25-31.

35. Estévez A, Delgado A, Hortelano P, et al. (1996) Characterization of mevalonate metabolism in the sea bass (Dicentrarchus labrax L.) liver. Fish Physiol Biochem 15 , 205-211.

36. Chen J (2006) Effects of fermentation, exogenous enzyme and feeding stimulants on utilization of soybean meal protein by Japanese flounder (Paralichthys olivaceus). PhD Thesis, Ocean University of China.

37. Hossain MA, Focken U \& Becker K (2002) Nutritional evaluation of dhaincha (Sesbania aculeata) seeds as dietary protein source for tilapia Oreochromis niloticus. Aquacult Res 33, 653-662.

38. Afuang WB, Siddhuraju P \& Becker K (2003) Comparative nutritional evaluation of raw, methanol extracted residues and methanol extracts of moringa (Moringa oleifera Lam.) leaves on growth performance and feed utilization in Nile 
tilapia (Oreochromis niloticus L.). Aquacult Res 34, 1147-1159.

39. Lu K, Lee MH \& Patel SB (2001) Dietary cholesterol absorption: more than just bile. Trends Endocrinol Metab 12, 314-320.

40. Park YB, Jeon SM, Byun SJ, et al. (2002) Absorption of intestinal free cholesterol is lowered by supplementation of Areca catechu L. extract in rats. Life Sci 70, 1849-1859.

41. Krogdahl A, Hemre GI \& Mommsen TP (2005) Carbohydrates in fish nutrition: digestion and absorption in postlarval stages. Aquacult Nutr 11, 103-122.

42. Hansen AC, Rosenlund G, Karlsen Ø, et al. (2007) Total replacement of fish meal with plant proteins in diets for Atlantic cod (Gadus morbua L.) I - effects on growth and protein retention. Aquaculture 272, 599-611.

43. Kumar V, Makkar HPS \& Becker K (2011) Nutritional, physiological and haematological responses in rainbow trout (Oncorbynchus mykiss) juveniles fed detoxified Jatropha curcas kernel meal. Aquacult Nutr 17, 451-467.

44. Garcia-Gonzalez M, Segovia JL \& Alejandre MJ (1992) Homeostatic restoration of microsomal lipids and enzyme changes in HMG-CoA reductase and acyl-CoA:cholesterol acyltransferase in chick liver. Mol Cell Biochem 115, 173-178.

45. Sun D, Fernandez ML, Lin EC, et al. (1999) Regulation of guinea pig hepatic acyl-CoA: cholesterol acyltransferase activity by dietary fat saturation and cholesterol. $J$ Nutr Biochem 10, 172-180.

46. Wang YM, Zhang B, Xue Y, et al. (2010) The mechanism of dietary cholesterol effects on lipids metabolism in rats. Lipids Health Dis 9, 4.

47. Erickson SK, Shrewsbury MA, Brooks C, et al. (1980) Rat liver acyl-CoA:cholesterol acyltransferase activity: its regulation in vivo and some of its properties in vitro. J Lipid Res 21, 930-941.

48. Mitropoulos KA, Venkatesan S, Synouri-Vrettakou S, et al. (1984) The role of plasma membranes in the transfer of non-esterified cholesterol to the acyl-CoA:cholesterol acyltransferase substrate pool in liver microsomal fraction. Biochim Biophys Acta 792, 227-237.

49. Bucher NLR, Overath P \& Lynen F (1960) 3-Hydroxy-3methylglutaryl coenzyme A reductase, cleavage, and condensing enzymes in relation to cholesterol formation in rat liver. Biochim Biophys Acta 40, 491-501.

50. Ness GC \& Chambers CM (2000) Feedback and hormonal regulation of hepatic 3-hydroxy-3-methylglutaryl coenzyme A reductase: the concept of cholesterol buffering capacity. Proc Soc Exp Biol Med 224, 8-19.

51. Andersen JM, Turley SD \& Dietschy JM (1982) Relative rates of sterol synthesis in the liver and various extrahepatic tissues of normal and cholesterol-fed rabbits: relationship to plasma lipoprotein and tissue cholesterol levels. Biochim Biophys Acta 711, 421-430.

52. Chambers CM \& Ness GC (1998) Dietary cholesterol regulates hepatic 3-hydroxy-3-methylglutaryl coenzyme A reductase gene expression in rats primarily at the level of translation. Arch Biochem Biphys 354, 317-322.
53. Turley SD, Spady DK \& Dietschy JM (1997) Regulation of fecal bile acid excretion in male golden Syrian hamsters fed a cereal-based diet with and without added cholesterol. Hepatology 25, 797-803.

54. Chiang JYL (2011) Bile acid metabolism. In Molecular Pathology of Liver Disease, pp. 165-179 [SPS Monga, editor]. New York, NY: Springer Verlag.

55. Jelinek DF, Andersson S, Slaughter CA, et al. (1990) Cloning and regulation of cholesterol $7 \alpha$-hydroxylase, the rate-limiting enzyme in bile acid biosynthesis. J Biol Chem 265 , 8190-8197.

56. Chapman MJ (1980) Animal lipoproteins: chemistry, structure, and comparative aspects. J Lipid Res 21, 789-853.

57. Higgs DA, Fagerlund UHM, Eales JG, et al. (1982) Application of thyroid and steroid hormones as anabolic agents in fish culture. Comp Biochem Physiol 73B, 143-176.

58. Sumpter JP (1992) Control of growth of rainbow trout. Aquaculture 100, 299-320.

59. Regost C, Arzel J \& Kaushik SJ (1999) Partial or total replacement of fish meal by corn gluten meal in diet for turbot Psetta maxima. Aquaculture 180, 99-117.

60. Glencross B, Evans D, Rutherford N, et al. (2006) The influence of the dietary inclusion of the alkaloid gramine, on rainbow trout (Oncorbynchus mykiss) growth, feed utilization and gastrointestinal histology. Aquaculture $\mathbf{2 5 3}$, 512-522.

61. Reddy PK \& Leatherland JF (2003) Influences of photoperiod and alternate days of feeding on plasma growth hormone and thyroid hormone levels in juvenile rainbow trout. $J$ Fish Biol 63, 197-212.

62. Fevolden SE, Røed KH \& Fjalestad KT (2002) Selection response of cortisol and lysozyme in rainbow trout and correlation to growth. Aquaculture 205, 61-75.

63. Zhou Q, Jimi S, Smith TL, et al. (1991) The effect of cholesterol on the accumulation of intracellular calcium. Biochim Biophys Acta 1085, 1-6.

64. Newcomb TW (1974) Changes in blood chemistry of juvenile steelhead trout, Salmo gairdneri, following sublethal exposure to nitrogen supersaturation. J Fish Res Board Can 31, 1953-1957.

65. Hirai K, Hasegawa M, Takezoe R, et al. (1993) Increases in serum levels of calcium and ratio of calcium to magnesium due to dietary cholesterol and their relationship to tocopherol in rats. Nutr Res 13, 489-497.

66. Sloan DR, Harms RH, Russeld GB, et al. (1964) The relationship of egg cholesterol to serum cholesterol, serum calcium, fed consumption and dietary cholecalciferol. Poult Sci $\mathbf{7 3}$, 472-475.

67. Ueda H, Matsumoto S \& Tanoue K (2004) Growth response and crop emptying in chicks force-fed diets containing various saponins. J Poult Sci 41, 298-306.

68. Mel'nikov SM, Seijen ten Hoorn JWM \& Eijkelenboom APAM (2004) Effect of phytosterols and phytostanols on the solubilisation of cholesterol by dietary mixed micelles: an in vitro study. Chem Phys Lipids 127, 121-141.

69. Farrell AP, Saunders RL, Freeman HC, et al. (1986) Arteriosclerosis in Atlantic salmon. Effects of dietary cholesterol and maturation. Arteriosclerosis 6, 453-461. 